\title{
Evaluation of diet and growth in children with and without atopic eczema: follow-up study from birth to 4 years
}

\author{
Kirsi Laitinen ${ }^{1,2^{*}}$, Marko Kalliomäki ${ }^{1}$, Tuija Poussa ${ }^{3}$, Hanna Lagström ${ }^{4}$ and Erika Isolauri ${ }^{1,5}$ \\ ${ }^{1}$ Department of Paediatrics, Turku University Central Hospital, Turku, Finland \\ ${ }^{2}$ Department of Biochemistry and Food Chemistry and Functional Foods Forum, University of Turku, Itäinen Pitkäkatu 4A, 5th Floor, \\ 20520 Turku, Finland \\ ${ }^{3}$ Stat-Consulting, Tampere, Finland \\ ${ }^{4}$ The Research Centre of Applied and Preventive Cardiovascular Medicine, University of Turku, Turku, Finland \\ ${ }^{5}$ Department of Paediatrics, University of Turku, Turku, Finland
}

(Received 3 February 2005 - Revised 7 April 2005 - Accepted 12 April 2005)

\begin{abstract}
Current research into dietary factors contributing to the development of allergic diseases is directed towards new active approaches instead of passive elimination diets. The present study aimed to investigate the explanatory role of the diet in a probiotic intervention study on the appearance of atopic eczema (AE) in childhood and the safety of perinatal supplementation with probiotics (Lactobacillus rhamnosus strain GG; ATCC 53 103). A prospective follow-up study from birth to 48 months of children ( $n$ 159) with a family history of allergic disease was carried out. Outcome measures included growth, dietary intake assessed with $4 \mathrm{~d}$ food diaries and their association with $\mathrm{AE}$ by logistic regression models. Increased intakes of retinol, Ca and $\mathrm{Zn}$, with perinatal administration of probiotics, reduced the risk of AE, whilst an increase in intake of ascorbic acid increased the likelihood of AE. Perinatal administration of probiotics was safe, as it did not influence the height (mean difference 0.04 (95\% CI $-0.33,0.40)$ SD scores, $P=0.852$ ) or the weight-for-height (mean difference $-3.35(95 \% \mathrm{CI}-7.07,0.37) \%, P=0.077)$ of the children at 48 months with and without perinatal administration of probiotics. Up to 48 months, AE did not affect height (mean difference $-0.05(95 \% \mathrm{CI}-0.42,0.33)$ SD scores, $P=0.815)$, but mean weight-for-height in children with AE was $-5.1 \%$ $(95 \%$ CI $-8.9,-1.2 \%)$ lower compared with children without $(P=0.010)$. The joint effects of nutrients and probiotics need to be considered in active prevention and management schemes for allergic diseases.
\end{abstract}

Atopic eczema: Nutrient intake: Growth: Probiotics

Symptoms compatible with allergic diseases are increasing in industrialized countries (Ninan \& Russell, 1992; Aberg et al. 1995). Allergic diseases not only hamper the daily life of children but may also influence their long-term health, as indicated by a decline in growth (Chang et al. 1982; Ferguson et al. 1982; Kristmundsdottir \& David, 1987; Massarano et al. 1993; Tiainen et al. 1995; Isolauri et al. 1998; Agostoni et al. 2000; Christie et al. 2002). Principal theories on the origins of allergic diseases are linked to changes in nutrition along with general environmental changes, which appear to shape the immune responder type of the host during a critical period of life to allergic-type immune responsiveness.

For natural reasons, the main interest in dietary factors with regard to allergic diseases has centred on proteins, the antigens. Food-derived antigens may initiate or exacerbate the symptoms of allergic diseases and consequently various elimination diets, i.e. exclusion of one or more foods from the diet, have been used in attempts to both prevent and manage allergic diseases. In the former case, elimination diets have proved unsuccessful (Zeiger \& Heller, 1995), whilst in the latter they form the basis for management of documented food allergies (Fiocchi et al. 2004). Both are associated with an increased risk of nutritional inadequacies resulting particularly from the elimination from the diet of key foods such as milk or cereals.

Beyond this, recent research has focused on active prevention schemes as opposed to passive elimination diets. Supplementation with nutrients, including fatty acids (Dunstan et al. 2003) and probiotics (Kalliomäki et al. 2001, 2003), due to their immunomodulatory properties, may play a role in reducing the risk of allergic disease. However, previous studies do not report the nutrient intakes in subjects' habitual diets. This calls for an evaluation of the contribution of early dietary composition and supplements and their interactions to the risk of allergic disease. We sought to investigate the contribution of early dietary factors in a probiotic intervention study on the appearance of atopic eczema (AE) in childhood. In addition, we report the safety of perinatal administration of probiotics and the dietary intake and growth of children with and without AE.

\section{Subjects and methods}

Subjects and study design

The study population consisted of children ( $n$ 159) with a family history of AE (i.e. mother, father and/or older sibling with atopic 
eczema, allergic rhinitis or asthma) who participated in a prospective allergy prevention study described in detail elsewhere (Kalliomäki et al. 2001, 2003). Briefly, in a double-blind placebo-controlled trial, Lactobacillus GG (Lactobacillus rhamnosus strain GG; ATCC 53 103) was administered prenatally to mothers and postnatally for 6 months to their infants. Children were followed for their clinical status during the first four years of life. Study visits took place at 3 weeks and at 3, 6, 12, 18, 24 and 48 months. The present paper reports dietary and growth data on children with and without $\mathrm{AE}$ at the ages of 6,12 and 48 months, and evaluates the explanatory role of diet for AE at 24 and 48 months. The study was approved by the First Ethical Committee of the Hospital District of SouthWest Finland. Informed consent was obtained from the children's parents.

\section{Clinical evaluation}

Weight and height were measured at each study visit, and biceps, triceps, subscapular and suprailiac skin fold thicknesses (Holtain Tanner/Whitehouse skinfold calliper; Marsden Weighing Group, Henley-on-Thames, Oxfordshire, UK) and mid-upper arm circumference were measured at the 48-month visit. To standardize data for age and sex, height standard deviation (SD) scores and weight proportional for height (weight-for-height, \%) were calculated using Finnish reference values (Sorva et al. 1984). Mid-upper arm muscle circumference (mid-upper arm circumference $(\mathrm{cm})$ minus pi times triceps skinfold $(\mathrm{cm})$ ) and proportion of body fat were calculated (Siri, 1961; Brook, 1971). Values less than -2 SD scores for height and less than $-20 \%$ for weight-forheight were considered low and $+20 \%$ for weight-for-height were considered high.

Diagnosis of $\mathrm{AE}$ was confirmed if the following features were detected: pruritus, facial and/or extensor involvement and chronic course (Hanifin, 1991). The last-mentioned criterion was fulfilled at 6- and 12-month study visits if there had been manifest eczema with a duration of 1 month or longer. At 24 and 48 months the criterion was fulfilled only if eczema evinced a chronic relapsing course, i.e. it had occurred at least twice with a duration of 1 month or longer. Cow's milk allergy (CMA) was diagnosed by doubleblind placebo-controlled cow's milk challenge at the age of 12 months. Clinical evaluation for the manifestation of $\mathrm{AE}$ was carried out by the same physician (M. K.).

\section{Dietary assessment}

Children who had their dietary intake recorded at the ages of 6,12 and 48 months and had their clinical status recorded for $\mathrm{AE}$ at the same time points and at 24 months were included in the analyses of dietary intake and association between diet and AE. In view of the unknown amounts suckled and the composition of individual breast milks, the food diaries of partially or exclusively breastfed infants were excluded when the intake of energy and nutrients was analysed. Four-day food diaries with household measures were filled in by the parents or by personnel if the child was in daycare. On each occasion the families were requested to keep a food record on certain days and also to include at least one weekend day. Food records were checked item by item for completeness and accuracy with the aid of a portion picture booklet at each study visit. If needed, missing portion sizes, food descriptions, food preparation methods, etc. were added. Energy and nutrient intakes were calculated with the Micro-Nutrica ${ }^{\circledR}$ compu- ter program (version 2.0; Research Centre for Social Insurance Institution, Turku, Finland), which uses the Food and Nutrient Data Base of the Social Insurance Institution and is constantly updated with manufacturers' data including commercial infant formula and foods. The program gives a reasonably good estimate of the intake of energy and most nutrients (Hakala et al. 1996).

\section{Statistical analysis}

Values are reported as mean with $95 \%$ CI, unless otherwise specified. Differences between children with and without $\mathrm{AE}$ were evaluated by the independent-samples $t$ test for continuous variables. The $\chi^{2}$ test or Fisher's exact test was used for dichotomous variables. The influence of $\mathrm{AE}$ on longitudinal growth, height (SD score) and weight-for-height (\%), separately, was analysed by repeated-measures ANOVA, where the intervention (Lactobacillus $G G v$. placebo) was included as a categorical covariate. At the age of 48 months the effect of $\mathrm{AE}$ and Lactobacillus $G G$ on growth was analysed by two-way ANOVA. In both analyses the effects of probiotics and $\mathrm{AE}$ are given as mean effect with $95 \%$ CI. To characterize dietary factors possibly explaining $\mathrm{AE}$ in children at the age of 24 and 48 months, three logistic regression models were formed for both ages, including the dietary variables measured at the age of 6 months (model A), at 12 months (model B) and at 6 and 12 months (model C). Variables introduced into the models included dietary intakes of vitamins and minerals $(\mu \mathrm{g} / \mathrm{d}$ or $\mathrm{mg} / \mathrm{d}$ or per MJ per $\mathrm{d})$ and fat $(\mathrm{g} / \mathrm{d}$ and $\%$ of energy), duration of exclusive (months) or total breast-feeding (months), breastfeeding status at 6 months (yes/no) and 12 months (yes/no), and administration of Lactobacillus $G G$ (yes/ no). In order to control for the possible confounding effect of maternal and paternal allergic disease, these were introduced into the models separately and together (yes/no). The criteria for entering and removing a variable were probability of $F$-toenter $\leq 0 \cdot 10$ and probability for $F$-to-remove $\geq 0 \cdot 15$. Odds ratios (OR) and $95 \% \mathrm{CI}$ for the final models were computed. A two-tailed $P$ value of $<0.05$ was considered statistically significant. All statistical analyses were performed using SPSS for Windows (version 12.0.1; SPSS Inc., Chicago, IL, USA).

\section{Results}

\section{Clinical characteristics}

AE was diagnosed in $29 \%(46 / 159)$ of children at the age of 6 months, $46 \%(65 / 140)$ at 12 months, $35 \%(46 / 132)$ at 24 months and $36 \%(39 / 107)$ at 48 months. At the age of 12 months, CMA was diagnosed in eighteen children (14\%). To describe the natural course of $\mathrm{AE}$ in the study population (Fig. 1), only children attending all study visits up to 48 months of age were examined to avoid bias caused by patient drop-outs. Forty-one per cent of the thirty-nine children with $\mathrm{AE}$ at 6 months persisted with $\mathrm{AE}$ during the whole follow-up, up to the age of 48 months. The proportion of children without evidence of $\mathrm{AE}$ decreased from $63 \%$ to $39 \%$, from 6 to 48 months, and $69 \%$ of those sixty-seven children healthy at 6 months were without $\mathrm{AE}$ during the whole follow-up. A total of sixty-five $(61 \%)$ out of all children were diagnosed with $\mathrm{AE}$ during the follow-up, thirty-nine $(60 \%)$ of them at the age of 6 months, twelve (18\%) at 12 months, seven (11\%) at 24 months and seven $(11 \%)$ at 48 months. 


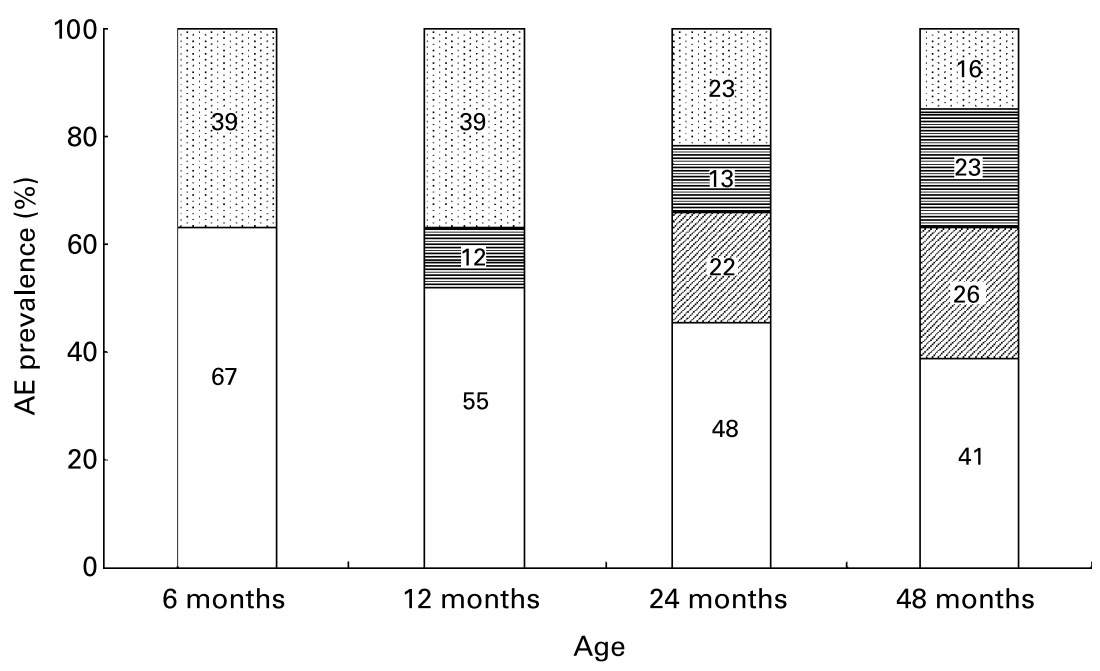

Fig. 1. Natural course of atopic eczema (AE) over the first four years of life. The bars represent the proportion (with numbers included in the bars) of subjects with/without $A E$ at different ages. ( $\square$ ), Without AE persistent from 6 months; (四), without $A E$ but a history with $A E$; (目), with $A E$ but a history without $A E$; (囼), with AE persistent from 6 months. Only children attending at all study visits were included.

\section{Dietary intake}

The mean duration of total breast-feeding was $6.8(95 \%$ CI $6 \cdot 1$, $7 \cdot 5)$ months and exclusive breast-feeding $2 \cdot 8(95 \%$ CI $2 \cdot 5,3 \cdot 1)$ months. At 6 months infants consumed 457 (95\% CI 400, 514) $\mathrm{ml}$ and at 12 months $371(95 \%$ CI 317, 426) $\mathrm{ml}$ of infant formula daily, when only infants consuming infant formula were accounted for. The mean daily intakes of energy and nutrients in the children with and without $\mathrm{AE}$ are shown in Tables 1 and 2. As no statistical difference was observed in dietary intake between sexes, males and females were combined for analysis. Children with AE had a lower intake of retinol at 6 months compared to those without. The intakes of protein and $\mathrm{Ca}$ were lower, and the intake of ascorbic acid higher, in children with $\mathrm{AE}$ than in those without at 12 months. At 48 months, the intakes of protein and $\mathrm{Ca}$ were lower, and the intake of cholecalciferol higher, in children with AE compared with those without.

The mean intake of energy per kg body weight was $97 \%(95 \%$ CI $86,109 \%)$ and $89 \%(95 \%$ CI $84,95 \%)$ of the reference intake (Nordic Nutrition Recommendations (NNR); Nordic Working Group on Diet and Nutrition, 1996) at 6 months $(P=0 \cdot 149)$, $97 \%(95 \%$ CI $91,103 \%)$ and $90 \%(95 \%$ CI 85, $96 \%)$ at 12 months $(P=0.086)$ and $84 \%(95 \% \mathrm{CI} 79,88 \%)$ and $81 \%$ $(95 \% \mathrm{CI} 77,84 \%)$ at 48 months $(P=0.320)$, in children with and without $\mathrm{AE}$, respectively. The mean intakes of macronutrients were within the range of recommended intake (NNR 1996) in both groups at 6 months (Table 1). At 12 months, the mean intake of protein was higher and the mean intake of fat lower, and at 48 months the intake of protein was higher and that of carbohydrates lower than the recommended intake in both groups (Table 1). The intakes of vitamins and minerals from the diet as a proportion of the recommended intake (NNR 1996), and a comparison between children with and without $\mathrm{AE}$, are shown in Fig. 2(a to c). At 6 months the mean intakes of $\mathrm{Zn}$ and $\mathrm{Fe}$ (\% of recommended) were higher in children with $\mathrm{AE}$ than in those without. The mean intakes of $\mathrm{Fe}$, ascorbic acid and vitamin $\mathrm{E}$ (\% of recommended) were higher and that of $\mathrm{Ca}$ lower in children with $\mathrm{AE}$ at 12 months; the mean intakes of ascorbic acid and cholecalciferol were higher in children with
$\mathrm{AE}$ at 48 months than in those without. The intakes of individual nutrients were below the recommendations for several nutrients, the most notable being $\mathrm{Zn}, \mathrm{Fe}, \mathrm{Ca}$ and cholecalciferol at 6 months; $\mathrm{Fe}, \mathrm{Ca}$ and cholecalciferol at 12 months; and $\mathrm{Fe}$, vitamin $\mathrm{E}$ and cholecalciferol at 48 months. In children with $\mathrm{AE}$ the intake of vitamin $\mathrm{A}(P=0.044)$ at 6 months and that of $\mathrm{Ca}(P=0.021)$ at 12 months were less than recommended more frequently compared with children without AE. Fe intake was less than recommended more frequently in children without $\mathrm{AE}$ compared with those with $\mathrm{AE}$ at 6 months $(P=0.004)$ and at 12 months $(P=0.020)$, whilst no difference was observed between the groups at 48 months.

Children diagnosed with CMA ( $n$ 14) at 12 months had higher intakes of energy (4525 (95\% CI 4140, 4910) kJ v. 3687 (95\% CI $3538,3836) \mathrm{kJ}, P<0.001)$ and fat as a proportion of total energy (33.0 (95\% CI 30.4, 35.7)\% v. 28.2 (95\% CI 26.9, 29.5)\%, $P=0.004)$ but a lower intake of protein as a proportion of total energy $(11.1 \quad(95 \%$ CI $10.3,11.8) \%$ v. 15.4 (95\% CI 14.7 , $16 \cdot 2) \%, P<0.001)$ than did infants without CMA $(n 81)$. Children with CMA had higher intakes of cholecalciferol, vitamin E, ascorbic acid and $\mathrm{Fe}$ and a lower intake of $\mathrm{Ca}$ than infants without CMA (data not shown). The intake of infant formula was higher $(658(95 \%$ CI 543, 774) $\mathrm{ml} / \mathrm{d})$ in children with CMA than without (238 (95\% CI 188, 288) ml/d, $P<0 \cdot 001)$.

\section{Growth and body composition}

The presence of AE did not affect height SD score or weight-forheight at different ages (Fig. 3(a and b)), except that children with AE (0.40 (95\% CI 0.17, 0.65) SD scores) were shorter than children without ( 0.73 (95\% CI 0.51, 0.96) SD scores, $P=0.048)$ at 24 months. One child ( $2 \%)$ with $\mathrm{AE}$ at 6 months and one $(2 \%)$ at 12 months had height less than -2 SD scores. The weight of one child $(2 \%)$ with $\mathrm{AE}$ at 6 months, one $(1 \%)$ without $\mathrm{AE}$ at 12 months and one $(1 \%)$ at 24 months was less than $20 \%$ of the population mean. One child with $\mathrm{AE}(2 \%)$ at 6 months and three $(3 \%)$ without $\mathrm{AE}$ at 6 months, one $(1 \%)$ at 12 months, two $(2 \%)$ at 24 months and five $(8 \%)$ at 48 months 
K. Laitinen et al.

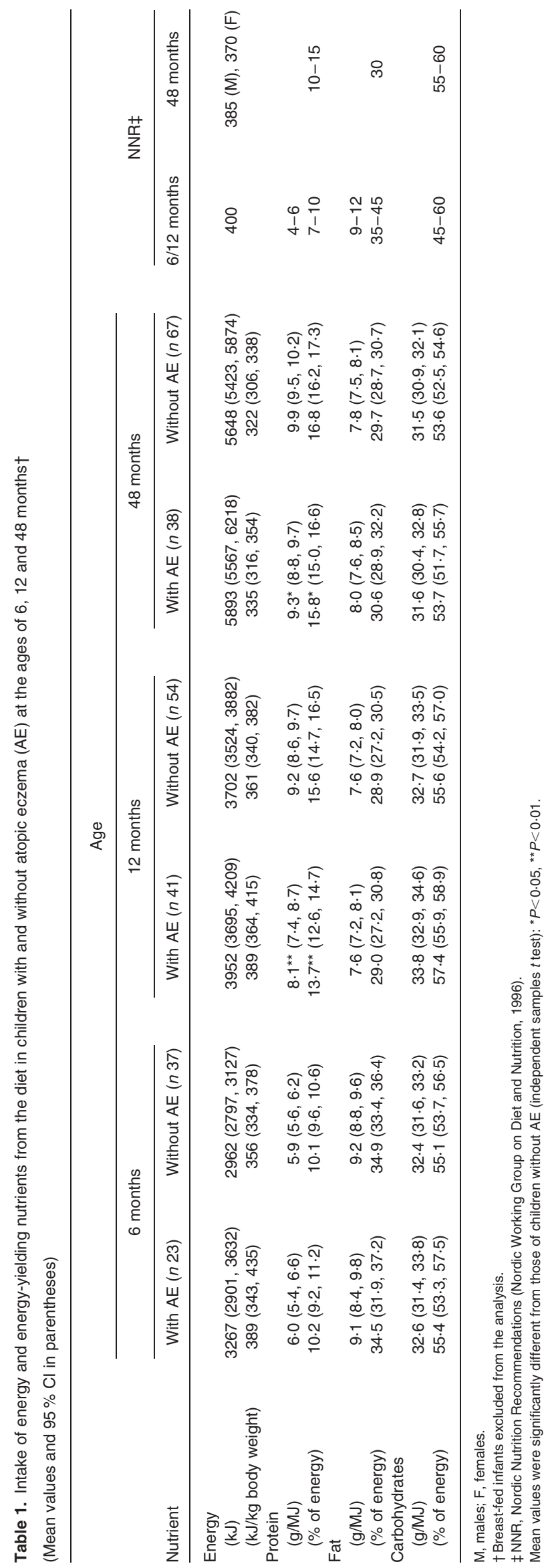


had weight above the $20 \%$ of the population mean (all dichotomic analyses between groups, NS).

According to longitudinal analysis (ANOVA for repeated measures from 6 to 48 months) using $\mathrm{AE}$ (at least one AE diagnosis during follow-up) and probiotics as explaining factors, neither AE nor probiotics significantly affected height. The mean difference for height during the follow-up from 6 to 48 months between children with $(n$ 60) and without $(n$ 38) AE was $0.02(95 \% \mathrm{CI}-0.30,0.35) \mathrm{SD}$ scores $(P=0.890)$. The mean weight-for-height was $-3.5 \%(95 \% \mathrm{CI}-6.5,-0.5 \%$, $P=0.025)$ lower in children with AE compared with those without. In the probiotic group the mean height was $-0 \cdot 1$ SD scores (95\% CI $-0.4,0.2, P=0.532)$ lower and the mean weight $-2.9 \%$ (95\% CI $-6 \cdot 0,0 \cdot 1, P=0.056$ ) lower compared with the children with perinatal administration of placebo.

Perinatal administration of probiotics proved safe, as it also did not significantly influence the height or weight-for-height of the children as measured at 48 months. According to two-way ANOVA with $\mathrm{AE}$ (at least one AE diagnosis during follow-up) and probiotics as explaining factors, the effect of perinatal administration of probiotics on height was 0.04 SD scores $(95 \%$ CI $-0.33,0.40, P=0.852)$ and on weight-for-height $-3.35 \%$ (95\% CI $-7.07,0.37, P=0.077$ ). However, the effect of AE at 48 months was significant with respect to weight, $-5.1 \%$ (95\% CI $-8.9,-1.2, P=0.010)$, but not height, $-0.05 \mathrm{SD}$ scores $(95 \% \mathrm{CI}-0.42,0 \cdot 33, P=0.815$ ).

The weight-for-height and height SD score of the children were not significantly affected by age at diagnosis (at 6 months or at 12,24 or 48 months) or age at appearance of symptoms (data not shown). The height ( 0.5 (95\% CI $0.08,1.0)$ SD scores) and weight-for-height $(-3(95 \% \mathrm{CI}-6,0.4) \%)$ of eighteen children with CMA at 12 months were within the population reference range.

Mid-upper arm muscle circumference (14.3 (95\% CI 14.0, 14.6) $\mathrm{cm}$ and $14.8(95 \%$ CI $14.4,15.1) \mathrm{cm}$ with and without $\mathrm{AE}, n 31$ and 49 , respectively, $P=0.041)$ and proportion of body fat $(14.1$ (95\% CI $12.7,15.4) \%$ and 16.6 (95\% CI 15.4 , 17.7)\% with and without $\mathrm{AE}, n 29$ and 45, respectively, $P=0 \cdot 007)$ were lower in children with AE compared with those without at 48 months.

\section{Association of dietary intake with atopic eczema}

According to the final logistic regression models (Table 3) the dietary factors, along with perinatal administration of Lactobacillus $G G$, which reduced the likelihood of $\mathrm{AE}$ at 24 months were increases in intake of retinol and $\mathrm{Ca}$ at all ages studied. A higher intake of fat at 6 months as well as maternal AE, but not paternal $\mathrm{AE}$, increased the likelihood of $\mathrm{AE}$ in the child at 24 months. The likelihood of $\mathrm{AE}$ at 48 months was explained by increases in ascorbic acid intake at all ages studied, whilst higher intakes of retinol and $\mathrm{Zn}$ reduced the likelihood of $\mathrm{AE}$ in the child.

\section{Discussion}

Previous nutritional approaches attempting to reduce the risk of allergic diseases have mainly involved the elimination of foods or environmental factors, based on the conception that allergen avoidance results in prevention of allergic disease. Current research is focusing more on active prevention schemes identifying factors 
(a)

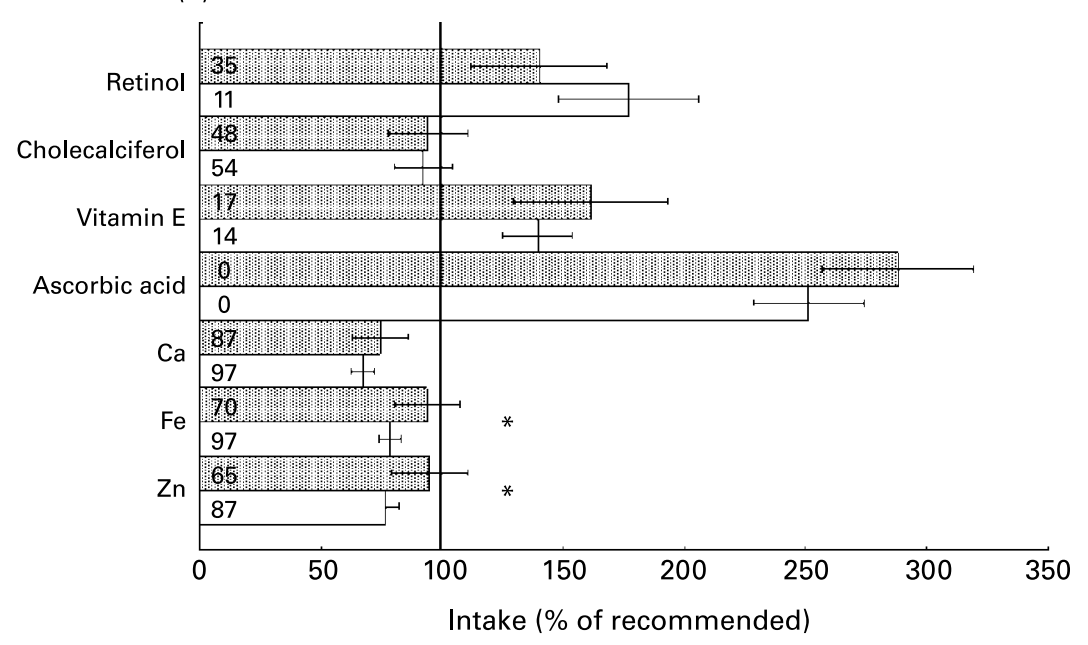

(b)

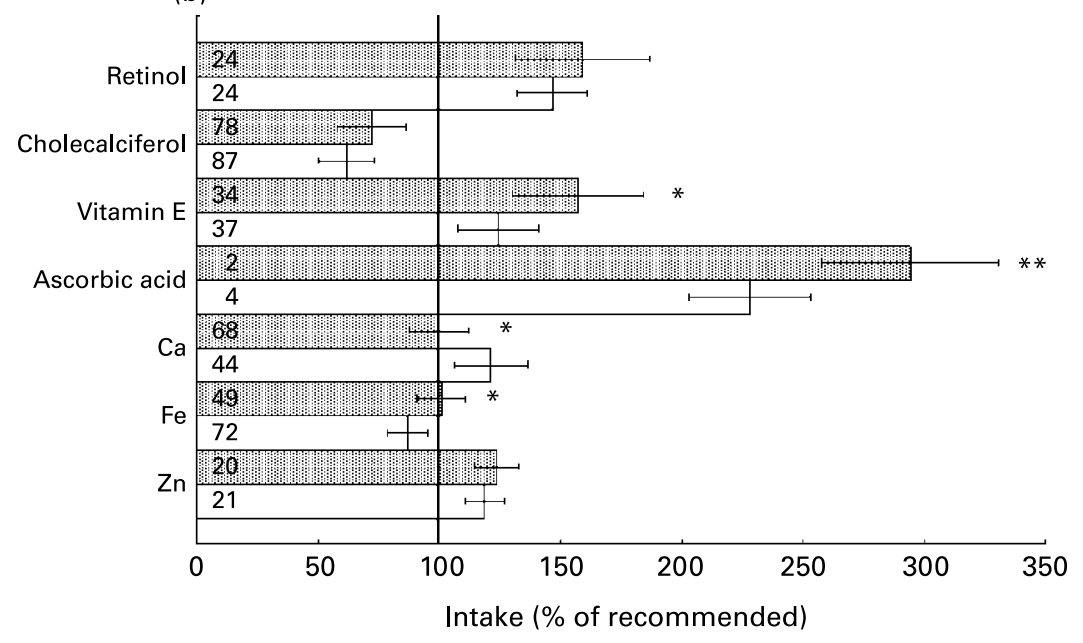

(c)

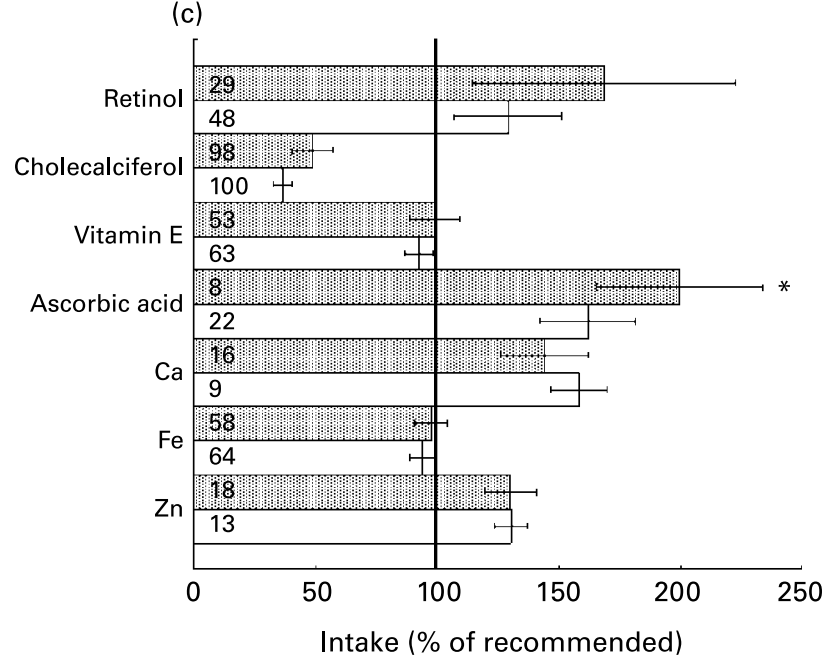

Fig. 2. Intake of nutrients from the diet (percentage of recommended intake; Nordic Working Group on Diet and Nutrition, 1996) in children with (圆) and without ( $\square$ ) atopic eczema (AE) at the age of (a) 6 months ( $n 23$ and $n 37$, respectively), (b) 12 months ( $n 41$ and $n 54$, respectively) and (c) 48 months ( $n 38$ and $n 67$, respectively). Breast-fed infants are excluded from the analysis. Values are means with their $95 \% \mathrm{Cl}$ shown by error bars and the numbers represent the proportion of individuals below $100 \%$ of recommended intake. Mean values were significantly different from those of children without AE (independent-samples $t$ test): ${ }^{\star} P<0.05,{ }^{\star \star} P<0.01$. 
possibly influencing immunoregulatory pathways in early life, for example those promoting tolerance against potentially harmful agents, including supplementation of nutrients or probiotics. We aimed to broaden the view of exclusion on one hand, and sole supplementation on the other, by providing a unifying approach in identifying the contribution of early dietary factors in a probiotic intervention study on the appearance of AE in childhood.

We showed that with careful monitoring of growth and management of $\mathrm{AE}$ in early childhood, the growth of patients
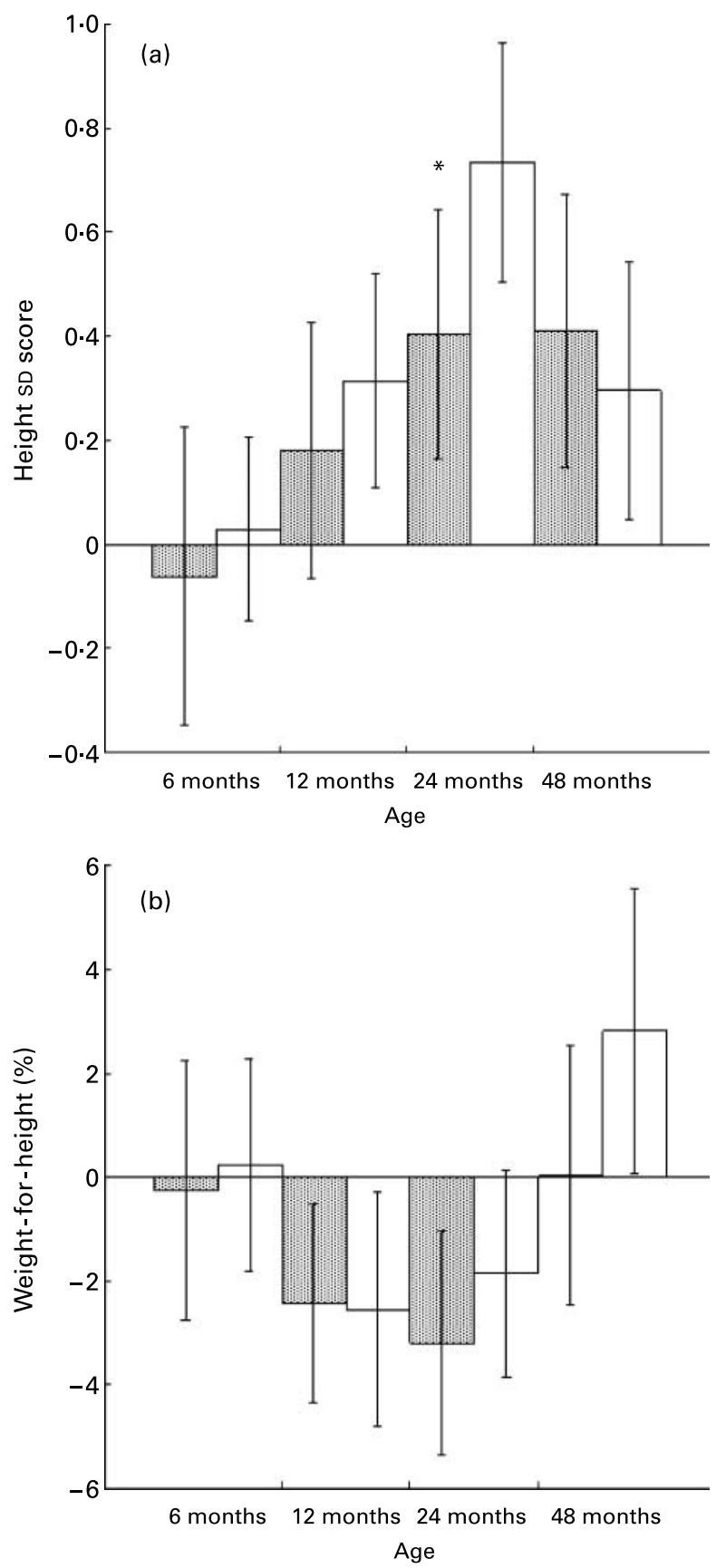

Fig. 3. (a) Height SD score and (b) weight proportional for height (weight-forheight, \%) in children with (圆) and without ( $\square$ ) atopic eczema (AE) at 6 ( $n 46$ and 87 , respectively), 12 ( $n 61$ and 70 , respectively), 24 ( $n 41$ and 83 , respectively) and 48 months of age ( $n 38$ and 64, respectively). Values are means with their $95 \% \mathrm{Cl}$ shown by error bars. Mean values were significantly different from those of children without $\mathrm{AE}$ (independent-samples $t$ test): ${ }^{\star} P<0.05$.
Table 3. Presence of atopic eczema at 24 and 48 months of age explained by diet at 6 (Model A), 12 (Model B) and at 6 and 12 months of age (Mode C). Results are based on stepwise logistic regression analysis, where dietary variables, Lactobacillus GG (Lactobacillus rhamnosus strain GG; ATCC 53103 ) administration, parental allergy and breast-feeding status were entered in the stepwise logistic regression model as potential explanatory variables

\begin{tabular}{|c|c|c|c|}
\hline & $B$ & $\begin{array}{l}\text { Odds ratio } \\
(95 \% \mathrm{Cl})\end{array}$ & $\begin{array}{c}P \\
\text { value }\end{array}$ \\
\hline \multicolumn{4}{|l|}{ Atopic eczema at 24 months } \\
\hline \multicolumn{4}{|l|}{ Model A ( $n$ 108) } \\
\hline Lactobacillus GG (yes/no) & $-1 \cdot 182$ & $0.31(0.12,0.78)$ & 0.013 \\
\hline Maternal allergy & $1 \cdot 398$ & $4.05(1.17,14.02)$ & 0.028 \\
\hline Fat intake at 6 months $(\mathrm{g} / \mathrm{d})$ & 0.061 & $1.06(0.99,1.14)$ & 0.092 \\
\hline $\begin{array}{l}\text { Retinol intake at } 6 \\
\text { months }(\mu \mathrm{g} / \mathrm{MJ} \text { per } \mathrm{d})\end{array}$ & -0.005 & $0.99(0.99,1.00)$ & 0.047 \\
\hline $\begin{array}{l}\text { Ca intake at } 6 \\
\text { months (mg/MJ per d) }\end{array}$ & -0.038 & $0.96(0.94,0.99)$ & 0.003 \\
\hline Constant & 2.459 & & 0.114 \\
\hline \multicolumn{4}{|l|}{ Model B ( $n 96)$} \\
\hline Lactobacillus GG (yes/no) & $-1 \cdot 150$ & $0.32(0.13,0.80)$ & 0.015 \\
\hline $\begin{array}{l}\text { Retinol intake at } 12 \\
\text { months }(\mu \mathrm{g} / \mathrm{MJ} \text { per } \mathrm{d})\end{array}$ & -0.008 & $0.99(0.98,1.00)$ & 0.062 \\
\hline $\begin{array}{l}\text { Ca intake at } 12 \\
\text { months (mg/MJ per d) }\end{array}$ & -0.008 & $0.99(0.98,1.00)$ & 0.053 \\
\hline Constant & $2 \cdot 270$ & & 0.023 \\
\hline \multicolumn{4}{|l|}{ Model C ( $n$ 81) } \\
\hline Lactobacillus GG (yes/no) & $-1 \cdot 344$ & $0.26(0.08,0.82)$ & 0.021 \\
\hline Maternal allergy & 1.455 & $4.29(0.90,20.41)$ & 0.068 \\
\hline $\begin{array}{l}\text { Retinol intake at } 6 \\
\text { months }(\mu \mathrm{g} / \mathrm{MJ} \text { per } \mathrm{d})\end{array}$ & -0.007 & $0.99(0.99,1.00)$ & 0.042 \\
\hline $\begin{array}{l}\text { Ca intake at } 6 \\
\text { months (mg/MJ per d) }\end{array}$ & -0.048 & $0.95(0.92,0.99)$ & 0.005 \\
\hline $\begin{array}{l}\text { Retinol intake at } 12 \\
\text { months ( } \mu \mathrm{g} / \mathrm{MJ} \text { per } \mathrm{d})\end{array}$ & -0.010 & $0.99(0.98,1.00)$ & 0.052 \\
\hline Constant & $7 \cdot 349$ & & 0.003 \\
\hline \multicolumn{4}{|l|}{ Atopic eczema at 48 months } \\
\hline $\begin{array}{l}\text { Ascorbic acid intake at } \\
6 \text { months (mg/MJ per d) }\end{array}$ & 0.059 & $1.06(1.00,1.12)$ & 0.039 \\
\hline Constant & $-2 \cdot 207$ & & 0.010 \\
\hline \multicolumn{4}{|l|}{ Model B ( $n 81)$} \\
\hline $\begin{array}{l}\text { Ascorbic acid intake at } \\
12 \text { months (mg/MJ per d) }\end{array}$ & 0.015 & $1.01(1.00,1.03)$ & 0.051 \\
\hline $\begin{array}{l}\text { Retinol intake at } 12 \\
\text { months ( } \mu \mathrm{g} / \mathrm{MJ} \text { per } \mathrm{d})\end{array}$ & -0.019 & $0.98(0.97,0.99)$ & 0.002 \\
\hline $\begin{array}{l}\text { Zn intake at } 12 \\
\text { months (mg/MJ per d) }\end{array}$ & -3.092 & $0.05(0.00,0.63)$ & 0.021 \\
\hline Constant & 5.903 & & 0.035 \\
\hline \multicolumn{4}{|l|}{ Model C ( $n$ 67) } \\
\hline $\begin{array}{l}\text { Ascorbic acid intake at } \\
12 \text { months }(\mathrm{mg} / \mathrm{d})\end{array}$ & 0.021 & $1.02(1.00,1.04)$ & 0.023 \\
\hline $\begin{array}{l}\text { Retinol intake at } 12 \\
\text { months ( } \mu \mathrm{g} / \mathrm{MJ} \text { per } \mathrm{d})\end{array}$ & -0.018 & $0.98(0.97,1.00)$ & 0.007 \\
\hline $\begin{array}{l}\text { Zn intake at } 12 \\
\text { months (mg/MJ per d) }\end{array}$ & $-3 \cdot 168$ & $0.04(0.00,0.87)$ & 0.040 \\
\hline Constant & $5 \cdot 383$ & & 0.086 \\
\hline
\end{tabular}

remained within population reference values and only $2 \%$ of children with $\mathrm{AE}$ at different ages were seen to evince poor growth. However, in the longitudinal analysis the mean weight of the children with $\mathrm{AE}$ was lowered by $3.5 \%$, and at 24 months they were shorter compared with those without AE. Additionally, they had less skeletal muscle protein mass at 48 months, as indicated by a lower mid-upper arm muscle circumference than children without $\mathrm{AE}$, which may reflect the lower dietary intake of protein or relate to $\mathrm{AE}$ itself through inflammation. 
Failure to thrive may culminate in patients not being regularly monitored, as the reasons for growth failure in $\mathrm{AE}$ are various. A sustained inflammation may result in reduced bioavailability or loss of nutrients (Ukabam et al. 1984), while metabolic requirements may be increased and the symptoms of the disease may be regulated by elimination of foods (Eggesbo et al. 2001). Patients may also develop food aversions, this resulting in inadequate dietary intake or replacement of foods by others and by infant formula, the use of which may extend to toddler age. Dietary adaptations may also explain the differences observed in nutrient intake between children with and without AE. In the present study the low energy intake compared with dietary reference values (NNR 1996) and figures in other studies (Räsänen \& Ylönen, 1992; Lagström et al. 1997) was not reflected in growth, but may equally be due to inaccurate or under-reporting of the diets. Also, other well-known limitations in reporting the nutrient intake from the food diary method need to be considered in interpretations of the results (Hakala et al. 1996). Dietary intake studies in children with $\mathrm{AE}$ are scant, but compared with figures for healthy children (Räsänen \& Ylönen, 1992; Lagström et al. 1997), the intakes of Zn, Fe, $\mathrm{Ca}$ (at 8 months) and cholecalciferol (Lagström et al. 1997), but also vitamin $\mathrm{E}$, were lower than reference nutrient intakes (NNR 1996) in a notable proportion of the children. The low intake of cholecalciferol at 48 months was particularly striking. At the time the study was undertaken, children were recommended to use vitamin D supplements up to the age of 24 months, which would have compensated for the low dietary intake. Since the study was conducted new recommendations on vitamin D supplementation for children and on fortification of dairy products have been given, the effects of which on intake and serum concentrations as well as on health outcomes should be evaluated. The early dietary intake of cholcecalciferol did not emerge as an explanatory factor for $\mathrm{AE}$ in the present study, but may none the less have immunomodulatory properties influencing later risk of diseases also, other than bone-related (Mathieu et al. 2004). Although nutritional consequences reflected in growth and dietary intake may be transient (Patel et al. 1997), the health consequences may be of long-lasting nature (Barker, 1995).

In the present study, additionally to the previously observed protective effect of the administration of probiotics (Kalliomäki et al. 2001, 2003), intakes of retinol comprising $\beta$-carotene, as well as $\mathrm{Ca}$ and $\mathrm{Zn}$, reduced the risk of $\mathrm{AE}$, whilst ascorbic acid intake increased the risk of AE. Dietary antioxidant vitamins have raised interest in allergic disease as they counteract oxidative stress and damp the inflammatory response, and may thus be important in implementing the ability of the individual to restrain the inflammatory response and allergic disease (Omata et al. 2001). Previous studies have, however, yielded contradictory results on the associations between dietary intake or serum concentrations of antioxidant vitamins and minerals and allergic disease (Powell et al. 1994; Soutar et al. 1997; Bodner et al. 1999; Hijazi et al. 2000; Picado et al. 2001; Arora et al. 2002; Nagel et al. 2003; Harik-Khan et al. 2004), which discrepancies may be explained by the different role of nutrients depending on the end-organ manifestation. Subjects in the present study evinced cutaneous involvement of the disease, whilst previously a low ascorbic acid intake (Soutar et al. 1997) or serum levels (Bodner et al. 1999; Harik-Khan et al. 2004) have been shown to relate to airway allergies. The disagreements may also result from the differences between the effects of dietary and supplemental nutrients arising from amounts consumed and compositional differences, as shown for vitamin E (Stone et al. 2003). In like manner, dietary intakes of nutrients may not reflect serum levels (Kardinaal et al. 1995), which on the other hand may not be a good indicator of body status. In one experimental study, although no difference was observed in serum retinol concentrations, the liver retinol concentration was lower in rats subjected to repeated allergen inhalation challenges compared with naïve rats (Shoseyov et al. 2002). The diet may also play a differential role in management and risk reduction in allergic disease. Most studies have been conducted in patients with existing disease and until now the role of nutrients in the prevention of $\mathrm{AE}$ has remained to be elucidated. One previous study has shown that low intake of ascorbic acid, via breast milk in infants, was associated with an increased risk of atopy (Hoppu et al. 2005). Another indication of the effects of maternal diet on the neonatal immune response was reduced cord blood IL-13 levels in neonates whose mothers received fish oil supplementation during pregnancy (Dunstan et al. 2003).

The mechanisms by which the nutrients retinol, $\mathrm{Ca}$ and $\mathrm{Zn}$, identified in the present study, may reduce the risk of $\mathrm{AE}$ remain unresolved, but their role may arise from the anti-oxidative properties of $\beta$-carotene, and of $\mathrm{Zn}$ as it acts as a cofactor in superoxide dismutase. $\mathrm{Ca}$ is an important intracellular messenger, required for the activation of phospholipase $\mathrm{A}_{2}$ and thus production of prostaglandin $\mathrm{E}_{2}$ with known effects on the modulation of cytokine and Ig profiles (Newberry et al. 1999). Retinol is also an important constituent for cell differentiation and thus for mucosal function above all in patients with gastrointestinal involvement of the disease. Retinoids have been found to inhibit IgE production in mouse peripheral blood mononuclear cells (Worm et al. 2001). Additionally, supplementation with vitamin A in mice resulted in depression of interferon- $\gamma$ and IL-4, the potential cytokines in allergic disease, and in increase in mucosal $\operatorname{IgA}$, with the capacity to protect mucosal surfaces (Albers et al. 2003). $\beta$-Carotene and retinol may also alter the activation of the arachidonic acid cascade and hence suppress prostaglandin $\mathrm{E}_{2}$ production in vitro (Halevy \& Sklan, 1987). This is a conflicting observation as in experimental studies prostaglandin $E_{2}$ has been shown to up-regulate IL-10 production (Harizi et al. 2002), important for the maintenance of healthy intestinal immune homeostasis, and to suppress antigen-specific $\mathrm{T}$ cell proliferation in gut-associated lymphoid tissue, thus contributing to an antiinflammatory intestinal environment (Newberry et al. 1999). Together with this, the sensitivity and the number of prostaglandin $\mathrm{E}_{2}$ receptors in the effector $\mathrm{T}$ cells may be reduced in AE (Rocklin et al. 1985; Rocklin \& Thistle, 1986), suggesting a beneficial role for prostaglandin $E_{2}$. Alternatively, the effects of retinol in $\mathrm{AE}$ may arise from its contribution to the innate immunity. Indeed, a deficiency of vitamin A impairs innate immunity by diminishing the function of neutrophils, macrophages and natural killer cells as well as antibody-mediated responses by $\mathrm{T}$ helper cells (reviewed in Stephensen, 2001). Finally, one explanation for the protective role of retinol observed in the present study could be that the efficacy of innate immunity requires an adequate intake of retinol, which strengthens the host-microbe interaction previously shown to control intestinal epithelial homeostasis (Rakoff-Nahoum et al. 2004).

It appears from the present study that the previously observed protective effect of probiotics (Lactobacillus GG; Kalliomäki 
et al. 2001, 2003) evolves in joint action with the dietary intake of particular nutrients, thus reducing the later risk of $\mathrm{AE}$ in a child. This finding calls for further evaluation of the interactions between nutrients and probiotics, the first attempt at which was made by evaluating the influence of PUFA on growth and adhesion of probiotics (Kankaanpää et al. 2001). Equally, the levels of dietary intakes of nutrients with potential capacity to reduce the risk of disease need to be re-evaluated bearing in mind the risk of using supplements at high doses or under certain conditions (Rietjens et al. 2002; Bjelakovic et al. 2004; Miller et al. 2004; Milner et al. 2004). The same holds true for weights to be lower in the group receiving probiotics perinatally, a circumstance not detected in a previous shorter study (Saavedra et al. 2004). Keeping in mind the need for further evaluations with subject numbers sufficiently sampled on these parameters, early dietary modification towards a balanced dietary intake of nutrients supplemented with probiotics may offer a preventive tool in the increasing problem of AE.

\section{Acknowledgements}

We thank the Academy of Finland, the Juho Vainio Foundation and the Wihuri Foundation for financial support; Ms Johanna Hvitfelt-Koskelainen and Ulla-Maija Eriksson for their contribution to contacts with the study subjects; Ms Soile Kotilainen for calculation of food diaries of children at 48 months; and Mr Robert MacGilleon for revision of the English text.

\section{References}

Aberg N, Hesselmar B, Aberg B \& Eriksson B (1995) Increase of asthma, allergic rhinitis and eczema in Swedish schoolchildren between 1979 and 1991. Clin Exp Allergy 25, 815-819.

Agostoni C, Grandi F, Scaglioni S, Gianni ML, Torcoletti M, Radaelli G, Fiocchi A \& Riva E (2000) Growth pattern of breastfed and nonbreastfed infants with atopic dermatitis in the first year of life. Pediatrics 106, e73.

Albers R, Bol M, Bleumink R, Willems AA \& Pieters RHH (2003) Effects of supplementation with vitamins $\mathrm{A}, \mathrm{C}$, and $\mathrm{E}$, selenium, and zinc on immune function in a murine sensitization model. Nutrition 19, 940-946.

Arora P, Kumar V \& Batra S (2002) Vitamin A status in children with asthma. Pediatr Allergy Immunol 13, 223-226.

Barker DJP (1995) Fetal origins of coronary heart disease. BMJ 311, 171-174.

Bjelakovic G, Nikolova D, Simonetti RG \& Gluud C (2004) Antioxidant supplements for prevention of gastrointestinal cancers: a systematic review and meta-analysis. Lancet 364, 1219-1228.

Bodner C, Godden D, Brown K, Little J, Ross S \& Seaton A on behalf of Aberdeen WHEASE Study Group (1999) Antioxidant intake and adultonset wheeze: a case-control study. Eur Respir J 13, 22-30.

Brook CGD (1971) Determination of body composition of children from skinfold measurements. Arch Dis Child 46, 182-184.

Chang KC, Miklich DR, Barwise G, Chai H \& Miles-Lawrence R (1982) Linear growth of chronic asthmatic children: the effects of the disease and various forms of steroid therapy. Clin Allergy 12, 369-378.

Christie L, Hine RJ, Parker JG \& Burks W (2002) Food allergies in children affect nutrient intake and growth. $J$ Am Diet Assoc 102, $1648-1651$.

Dunstan JA, Mori TA, Barden A, Beilin LJ, Taylor AL, Holt PG \& Prescott SL (2003) Maternal fish oil supplementation in pregnancy reduces interleukin-13 levels in cord blood of infants at high risk of atopy. Clin Exp Allergy 33, 442-448.
Eggesbo M, Botten G \& Stigum H (2001) Restricted diets in children with reactions to milk and egg perceived by their parents. J Pediatr 139, 583-587.

Ferguson AC, Murray AB \& Tze WJ (1982) Short stature and delayed skeletal maturation in children with allergic disease. J Allergy Clin Immunol 69, 461-466.

Fiocchi A, Bouygue GR, Martelli A, Terracciano L \& Sarratud T (2004) Dietary treatment of childhood atopic eczema/dermatitis syndrome (AEDS). Allergy 59, Suppl., 78-85.

Hakala P, Marniemi J, Knuts L-R, Kumpulainen J, Tahvonen R \& Plaami S (1996) Calculated vs analysed nutrient composition of weight reduction diets. Food Chem 57, 71-75.

Halevy O \& Sklan D (1987) Inhibition of arachidonic acid oxidation by $\beta$-carotene, retinol, and $\alpha$-tocopherol. Biochim Biophys Acta 918, 304-307.

Hanifin JM (1991) Atopic dermatitis in infants and children. Pediatr Clin North Am 38, 763-789.

Harik-Khan RI, Muller DC \& Wise RA (2004) Serum vitamin levels and the risk of asthma in children. Am J Epidemiol 159, 351-357.

Harizi H, Juzan M, Pitard V, Moreau J-F \& Gualde N (2002) Cyclooxygenase-2-issued prostaglandin $\mathrm{E}_{2}$ enhances the production of endogenous IL-10, which down-regulates dendritic cell functions. J Immunol 168, 2255-2263.

Hijazi N, Abalkhail B \& Seaton A (2000) Diet and childhood asthma in a society in transition: a study in urban and rural Saudi Arabia. Thorax 55, 775-779.

Hoppu U, Rinne M, Salo-Väänänen P, Lampi A-M, Piironen V \& Isolauri E (2005) Vitamin C in breast milk may reduce the risk of atopy in the infant. Eur J Clin Nutr 59, 123-128.

Isolauri E, Sütas Y, Salo MK, Isosomppi R \& Kaila M (1998) Elimination diet in cow's milk allergy: risk for impaired growth in young children. $J$ Pediatr 132, 1004-1009.

Kalliomäki M, Salminen S, Arvilommi H, Kero P, Koskinen P \& Isolauri E (2001) Probiotics in primary prevention of atopic disease: a randomised, placebo-controlled trial. Lancet 357, 1076-1079.

Kalliomäki M, Salminen S, Poussa T, Arvilommi H \& Isolauri E (2003) Probiotics and prevention of atopic disease - a 4-year follow-up of a randomised placebo-controlled trial. Lancet 361, 1869-1871.

Kankaanpää PE, Salminen S, Isolauri E \& Lee YK (2001) The influence of polyunsaturated fatty acids on probiotic growth and adhesion. FEMS Microbiol Lett 194, 149-153.

Kardinaal AFM, van't Veer P, Brants HAM, van den Berg H, van Schoonhoven J \& Hermus RJJ (1995) Relations between antioxidant vitamins in adipose tissue, plasma, and diet. Am J Epidemiol 141, 440-450.

Kristmundsdottir F \& David TJ (1987) Growth impairment in children with atopic eczema. $J$ R Soc Med 80, 9-12.

Lagström H, Jokinen E, Seppänen R, et al. (1997) Nutrient intakes by young children in a prospective randomized trial of a low-saturated fat, low-cholesterol diet. The STRIP baby project. Arch Pediatr Adolesc Med 151, 181-188.

Massarano AA, Hollis S, Devlin J \& David TJ (1993) Growth in atopic eczema. Arch Dis Child 68, 677-679.

Mathieu C, van Etten E, Decallone B, Guilietti A, Gysemans C, Bouillon R \& Overbergh L (2004) Vitamin D and 1,25-dihydroxyvitamin $\mathrm{D}_{3}$ as modulators in the immune system. J Steroid Biochem Mol Biol 89-90, 449-452.

Miller ER, Pastor-Barriuso R, Dalal D, Riemersma RA, Appel L \& Guallar E (2004) Meta-analysis: high-dosage vitamin E supplementation may increase all-cause mortality. Ann Intern Med 142, 37-46.

Milner JD, Stein DM, McCarter R \& Moon RY (2004) Early infant multivitamin supplementation is associated with increased risk for food allergy and asthma. Pediatrics 114, 27-32.

Nagel G, Nieters A, Becker N \& Linseisen J (2003) The influence of the dietary intake of fatty acids and antioxidants on hay fever in adults. Allergy 58, 1277-1284 
Newberry RD, Stenson WF \& Lorenz RG (1999) Cyclooxygenase-2dependent arachidonic acid metabolites are essential modulators of the intestinal immune response to dietary antigen. Nat Med 5, 900-906.

Ninan TK \& Russell G (1992) Respiratory symptoms and atopy in Aberdeen schoolchildren: evidence from two surveys 25 years apart. BMJ 304, 873-875.

Nordic Working Group on Diet and Nutrition (1996) Nordic Nutrition Recommendations. Scand J Nut 40, 161-165.

Omata N, Tsukahara H, Ito S, et al. (2001) Increased oxidative stress in childhood atopic dermatitis. Life Sci 69, 223-228.

Patel L, Clayton PE, Jenney MEM, Ferguson JE \& David TJ (1997) Adult height in patients with childhood onset atopic dermatitis. Arch Dis Child 76, 505-508.

Picado C, Deulofeu R, Lleonart R, Agusti M, Mullol J, Quinto L \& Torra M (2001) Dietary micronutrients/antioxidants and their relationship with bronchial asthma severity. Allergy 56, 43-49.

Powell CVE, Nash AA, Powers HJ \& Primhak RA (1994) Antioxidant status in asthma. Pediatr Pulmonol 18, 34-38.

Rakoff-Nahoum S, Paglino J, Eslami-Varzaneh F, Edberg S \& Medzhitov $\mathrm{R}$ (2004) Recognition of commensal microflora by toll-like receptors is required for intestinal homeostasis. Cell 118, 229-241.

Räsänen L \& Ylönen K (1992) Food consumption and nutrient intake of one- to two-year-old Finnish children. Acta Paediatr 81, 7-11.

Rietjens IMCM, Boersma MG, de Haan L, Spenkelink B, Awad HM, Cnubben NHP, van Zanden JJ, van der Woude H, Alink GM \& Koeman JH (2002) The pro-oxidant chemistry of the natural antioxidants vitamin C, vitamin E, carotenoids and flavonoids. Environ Toxicol Pharmacol 11, 321-333.

Rocklin RE \& Thistle L (1986) Reduced prostaglandin $\mathrm{E}_{2}\left(\mathrm{PGE}_{2}\right)$ receptors on atopic T lymphocytes. Cell Immunol 99, 294-299.
Rocklin RE, Thistle L \& Audera C (1985) Decreased sensitivity of atopic mononuclear cells to prostaglandin $\mathrm{E}_{2}\left(\mathrm{PGE}_{2}\right)$ and prostaglandin $\mathrm{D}_{2}$ (PGD $\left.{ }_{2}\right)$. J Immunol 135, 2033-2039.

Saavedra JM, Abi-Hanna A, Moore N \& Yolken RH (2004) Long-term consumption of infant formulas containing live probiotic bacteria: tolerance and safety. Am J Clin Nutr 79, 261-267.

Shoseyov D, Bibi H, Biesalski H \& Reifen R (2002) Repeated allergen challenge in rats increases vitamin A consumption. Chest 122, 1407-1411.

Siri WE (1961) Body volume measurements by gas dilution. In Techniques for Measuring Body Composition, pp. 108-117 [J Brozek and A Henschel, editors]. Washington, DC: National Academy of Sciences.

Sorva R, Perheentupa J \& Tolppanen EM (1984) A novel format for growth chart. Acta Paediatr 73, 527-529.

Soutar A, Seaton A \& Brown K (1997) Bronchial reactivity and dietary antioxidants. Thorax 52, 166-170.

Stephensen CB (2001) Vitamin A, infection, and immune function. Annu Rev Nutr 21, 167-192.

Stone WL, LeClair I, Ponder T, Baggs G \& Barret Reis B (2003) Infants discriminate between natural and synthetic vitamin E. Am J Clin Nutr 77, 899-906.

Tiainen JM, Nuutinen OM \& Kalavainen MP (1995) Diet and nutritional status in children with cow's milk allergy. Eur J Clin Nutr 49, 605-612.

Ukabam SO, Mann RJ \& Cooper BT (1984) Small intestinal permeability to sugars in patients with atopic eczema. Br J Dermatol 110, 649-652.

Worm M, Herz U, Krah JM, Renz H \& Henz BM (2001) Effects of retinoids on in vitro and in vivo IgE production. Int Arch Allergy Immunol 124, 233-236.

Zeiger RS \& Heller S (1995) The development and prediction of atopy in high-risk children: follow-up at age seven years in a prospective randomized study of combined maternal and infant food allergen avoidance. J Allergy Clin Immunol 95, 1179-1190. 